\title{
Degradation of 4-chlorophenol in $\mathrm{TiO}_{2}, \mathrm{WO}_{3}, \mathrm{SnO}_{2}$, $\mathrm{TiO}_{2} / \mathrm{WO}_{3}$ and $\mathrm{TiO}_{2} / \mathrm{SnO}_{2}$ systems
}

\author{
Cheng-Fang Lin ${ }^{\mathrm{a}}$, Chung-Hsin Wu ${ }^{\mathrm{b}, *}$, Zong-Nan Onn ${ }^{\mathrm{a}}$ \\ ${ }^{a}$ Graduate Institute of Environmental Engineering, National Taiwan University, 71, Chou-Shan Road, Taipei, Taiwan \\ ${ }^{\mathrm{b}}$ Department of Environmental Engineering, Da-Yeh University, 112, Shan-Jiau Road, Da-Tsuen, Chang-Hua, Taiwan
}

Received 23 August 2007; received in revised form 19 October 2007; accepted 3 November 2007

Available online 13 November 2007

\begin{abstract}
The present study was undertaken to evaluate the degradation performance of 4-chlorophenol (4-CP) using $\mathrm{TiO}_{2} / \mathrm{WO}_{3}$ and $\mathrm{TiO}_{2} / \mathrm{SnO}_{2}$ systems . A BET surface area analyzer, UV-vis spectroscopy, scanning electron microscopy (SEM), X-ray diffraction (XRD) and electron spectroscopy for chemical analysis (ESCA) were employed to characterize the photocatalyst. The band edge wavelength increased to $475 \mathrm{~nm}$ and gap energy decreased to $2.61 \mathrm{eV}$ in the $\mathrm{TiO}_{2} / \mathrm{WO}_{3}$ system as compare to the single $\mathrm{TiO}_{2}$. Although the specific surfaces area of $\mathrm{TiO}_{2} / \mathrm{WO}_{3}$ decreases due to its larger size as compared to either $\mathrm{TiO}_{2}$ or $\mathrm{WO}_{3}$, the 4-CP degradation efficiency significantly increased as compared to single $\mathrm{TiO}_{2}$ or $\mathrm{WO}_{3}$ system at $435 \mathrm{~nm}$ wavelength. The $\mathrm{TiO}_{2} / \mathrm{WO}_{3}$ degradation of $4-\mathrm{CP}$ at $369 \mathrm{~nm}$ was in fact inhibited. For $\mathrm{TiO}_{2} / \mathrm{SnO}_{2}$, the degradation efficiency also suffered at $369 \mathrm{~nm}$, and only slightly increased compared to otherwise hardly 4-CP degraded in single $\mathrm{TiO}_{2}$ or $\mathrm{SnO}_{2}$ system. Since there is a significant accumulation of byproducts, the buildup of these intermediates on the catalyst surface may be responsible for their poor performance.

(C) 2007 Elsevier B.V. All rights reserved.
\end{abstract}

Keywords: $\mathrm{TiO}_{2} ; \mathrm{SnO}_{2} ; \mathrm{WO}_{3} ; 4$-Chlorophenol; Photocatalyst

\section{Introduction}

Among different advanced oxidation processes, photocatalytic processes using semiconductor materials such as $\mathrm{TiO}_{2}$ have been demonstrated as effective means for organic degradation. The hydroxyl radical mediated reaction depends on the type and dosage of catalyst, type and concentration of pollutant, light intensity, and operating conditions such as temperature, $\mathrm{pH}$ and irradiation time. In order to have a practical application, the use of visible light source along with an enhanced degradation rate is essential. This can be achieved via the modification of semiconductors [1], addition of transition metals [2,3] and other element doping [4] as well as use of coupled semiconductors. Serpone et al. [5] initially proposed interparticle electron transfer theory in that light excites semiconductor with a smaller energy band gap to photosensitize another semiconductor with a higher electrical potential and larger band gap to enhance pho-

\footnotetext{
* Corresponding author. Fax: +886 55334958.

E-mail address: chunghsinwu@ yahoo.com.tw (C.-H. Wu).
}

tocatalytic reaction. Since then, coupled semiconductors have been used intensively for organic degradation in both aqueous and gas phase, including $\mathrm{TiO}_{2} / \mathrm{CdS}[6,7], \mathrm{TiO}_{2} / \mathrm{SnO}_{2}$ [8-11], $\mathrm{TiO}_{2} / \mathrm{ZnO}[12]$ and $\mathrm{TiO}_{2} / \mathrm{WO}_{3}[13,14]$. In general, the coupled systems exhibit higher degradation rate as well as the increased extent of degradation. The studies for comparing the coupled semiconductors with either UV or visible light; however, are scarce.

Consequently, the present study was undertaken to investigate the capability of coupled semiconductor systems to degrade a model compound (4-chlorpphenol, 4-CP). Two coupled system were used $\left(\mathrm{TiO}_{2} / \mathrm{SnO}_{2}\right.$ and $\left.\mathrm{TiO}_{2} / \mathrm{WO}_{3}\right)$ at wavelength 369 or $435 \mathrm{~nm}$ so that the efficiencies of these two light irradiations could be compared. The physical characters of the coupled system were quantified by different methods: BET for the specific surface area; X-ray defractor (XRD) for crystal structure; UV-vis spectroscopy for determining band edge; scanning electron microscope (SEM) for size estimate; and X-ray electron spectroscopy (XPS) for determining distribution of $\mathrm{SnO}_{2}$ or $\mathrm{WO}_{3}$ in $\mathrm{TiO}_{2}$. For comparison, a single system of $\mathrm{WO}_{3}, \mathrm{TiO}_{2}$, or $\mathrm{SnO}_{2}$ was used. 


\section{Materials and methods}

\subsection{Materials}

$\mathrm{TiO}_{2}$ (Degussa P-25), $\mathrm{SnO}_{2}\left(99 \%\right.$, Ridel-de-Haen) and $\mathrm{WO}_{3}$ (99.9\%, Hanawa) were used as received without any pretreatment. The model compound 4-CP was purchased from Avocado Co. Other chemicals used were reagent grade and deionized water was used. The coupled $\mathrm{TiO}_{2} / \mathrm{SnO}_{2}$ was synthesized via citric acid complexing method, followed the procedures of Lin et al. [15]. Briefly, $\mathrm{TiCl}_{4}\left(98 \%\right.$, Fluka) and $\mathrm{SnCl}_{4}$ (99\%, Ridelde-Haen) was added into the aqueous $\mathrm{HCl}$ solution; addition of citric acid; sonification mixing for $15 \mathrm{~min}$ and aging for $24 \mathrm{~h}$; removal of $\mathrm{HCl}$ and $\mathrm{H}_{2} \mathrm{O}$ upon heating; calcined the resultant precipitate at $400^{\circ} \mathrm{C}$ for $3 \mathrm{~h}$.

The synthesis for $\mathrm{TiO}_{2} / \mathrm{WO}_{3}$ followed the incipient wetness procedures of Kwon et al. [13]. Since a $3 \%$ molar ratio of $\mathrm{WO}_{3}$ was found to exert a maximum decomposition of 1,4dichlorobenezene in an $\mathrm{TiO}_{2} / \mathrm{WO}_{3}$ system [13,16], the initial molar ratio of $\mathrm{H}_{2} \mathrm{WO}_{4}(98 \%)$ and $\mathrm{TiO}_{2}$ of 3:97 was used in an $25 \%$ ammonium solution. The mixture was dried, calcined at a rate of $100^{\circ} \mathrm{C} / \mathrm{h}$ to $400^{\circ} \mathrm{C}$; and then held for $2 \mathrm{~h}$ at $400^{\circ} \mathrm{C}$.

\subsection{Experiments}

The hollow cylindrical photo reactor has an effective volume of 3 L. The lamp (Wisdoms Electric \& Lighting Co.) at either 369 or $435 \mathrm{~nm}$ was placed inside the tube. The overall study consisted of 3 single catalysts and two coupled systems for degrading 4-CP. All experiments were performed with the same power consumption $(50 \mathrm{~W})$, catalyst dosage $(1.2 \mathrm{~g} / \mathrm{L})$, the initial $4-\mathrm{CP}$ concentration $(0.2 \mathrm{mM}$; initial TOC $=17.2 \mathrm{mg} / \mathrm{L})$, and temperature $\left(25^{\circ} \mathrm{C}\right)$. Three $\mathrm{pHs}(4,7$ and 10$)$ were used at the wavelength either 369 or $435 \mathrm{~nm}$. The $\mathrm{pH}$ of the solution was controlled by adding $\mathrm{HNO}_{3}$ and $\mathrm{NaOH}$ via an automatic titrator. During the course of experiments, the reactor content was continuously mixed $(300 \mathrm{rpm})$ and aerated; samples were periodically withdrawn, filtered $(0.45 \mu \mathrm{m})$ and filtrate was subsequently analyzed for TOC, chloride and 4-CP.

Several experiments were initially conducted to determine the extent of potential volatilization (no light, no catalyst with aeration), photolysis (no catalyst with aeration at 369 or $435 \mathrm{~nm}$ light) and catalytic reaction (catalyst without light and without aeration) of 4-CP. The results indicated no appreciable degradation of 4-CP after 200 min under the above three blank conditions. Reproducibility study was evaluated for several tests and the results were within $5 \%$.

\subsection{Analysis}

The specific surface area of each photocatalyst was determined via BET method (Micrometric TrtStar 3000). The absorption of catalysts over the entire spectrum $(190-800 \mathrm{~nm})$ was monitored in a UV-vis spectroscopy (GBC, Cintra 20) to determine semiconductor band gap energy. The model compound, 4-CP, was monitored in an HPLC (Millipore Waters $600 \mathrm{E}, 470)$ at the detector wavelength $254 \mathrm{~nm}$. The flow rate for mobile phase $\left(\mathrm{CH}_{3} \mathrm{CN}: \mathrm{H}_{2} \mathrm{O}: \mathrm{CH}_{3} \mathrm{COOH}=50: 50: 1\right)$ was $1 \mathrm{~mL} / \mathrm{min}$. TOC was measured in an OI TOC analyzer (Model 1010); chloride in an ion chromatograph (Dionex DX-120) with an eluent solution of $\mathrm{NaHCO}_{3} / \mathrm{Na}_{2} \mathrm{CO}_{3}$.

The SEM diagrams were obtained from LEO (1530); XRD patterns were obtained using a Philips diffractometer (X'pert Pro) at $45 \mathrm{kV}$ and current $40 \mathrm{~mA}$. The wavelength of $\mathrm{Cu} \mathrm{K \alpha}$ radiation used was $1.541 \AA$ with a scan range of $2 \theta$ between $20^{\circ}$ and $80^{\circ}$. Electron spectroscopy for chemical analysis (ESCA) was performed at $1486 \mathrm{eV}$ (VG Scientific, ESCALAB 250) to investigate surface composition.

Sodium salcylate, as a trapping agent for hydroxyl radicals, was used to determine the extent of their production [17]. The byproducts of 2, 3-dihydroxybenzoic acid, 2, 5dihydroxybenzoic acid and catechol were monitored at UV wavelength 318,306 and $275 \mathrm{~nm}$, respectively. The sum of hydroxylated derivates indicates the relative hydroxyl radical concentration.

\section{Results and discussion}

\subsection{Characterization of catalysts}

The BET results indicate lower specific surface area for the coupled $\mathrm{TiO}_{2}$ catalysts as compared to single $\mathrm{TiO}_{2}$ (Table 1). From the absorbance data of the entire UV-vis wavelength of each catalyst (Fig. 1), the band edge wavelength for each catalyst could be determined and the resultant band gap energies calculated [21] as shown in Table 1. While the band edge of $\mathrm{TiO}_{2} / \mathrm{WO}_{3}$ increases to $475 \mathrm{~nm}$ compared to the single $\mathrm{TiO}_{2}(390 \mathrm{~nm})$ or $\mathrm{WO}_{3}(450 \mathrm{~nm})$, that of $\mathrm{TiO}_{2} / \mathrm{SnO}_{2}(380 \mathrm{~nm})$ slightly decreases

Table 1

Characterization of catalysts used in the present study

\begin{tabular}{|c|c|c|c|c|c|}
\hline Sample & Band edge wavelength (nm) & Band gap energy (eV) & Specific surface area $\left(\mathrm{m}^{2} / \mathrm{g}\right)$ & Size (nm) & Atom (\%) \\
\hline $\mathrm{TiO}_{2}$ & 390 & 3.18 & $54^{\mathrm{a}}$ & $24^{\mathrm{b}}$ & - \\
\hline $\mathrm{SnO}_{2}$ & 335 & 3.70 & $4.8^{\mathrm{a}}$ & $59^{\mathrm{b}}$ & - \\
\hline $\mathrm{WO}_{3}$ & 450 & 2.76 & 1.0 & $42^{\mathrm{c}}$ & - \\
\hline $\mathrm{TiO}_{2} / \mathrm{SnO}_{2}$ & 380 & 3.27 & 12.4 & 150 & Ti2p:Sn3d=95:5 \\
\hline $\mathrm{TiO}_{2} / \mathrm{WO}_{3}$ & 475 & 2.61 & 37.1 & 300 & Ti2p:W4f = 76:24 \\
\hline
\end{tabular}

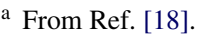

b From Ref. [19].

c From Ref. [20].
} 


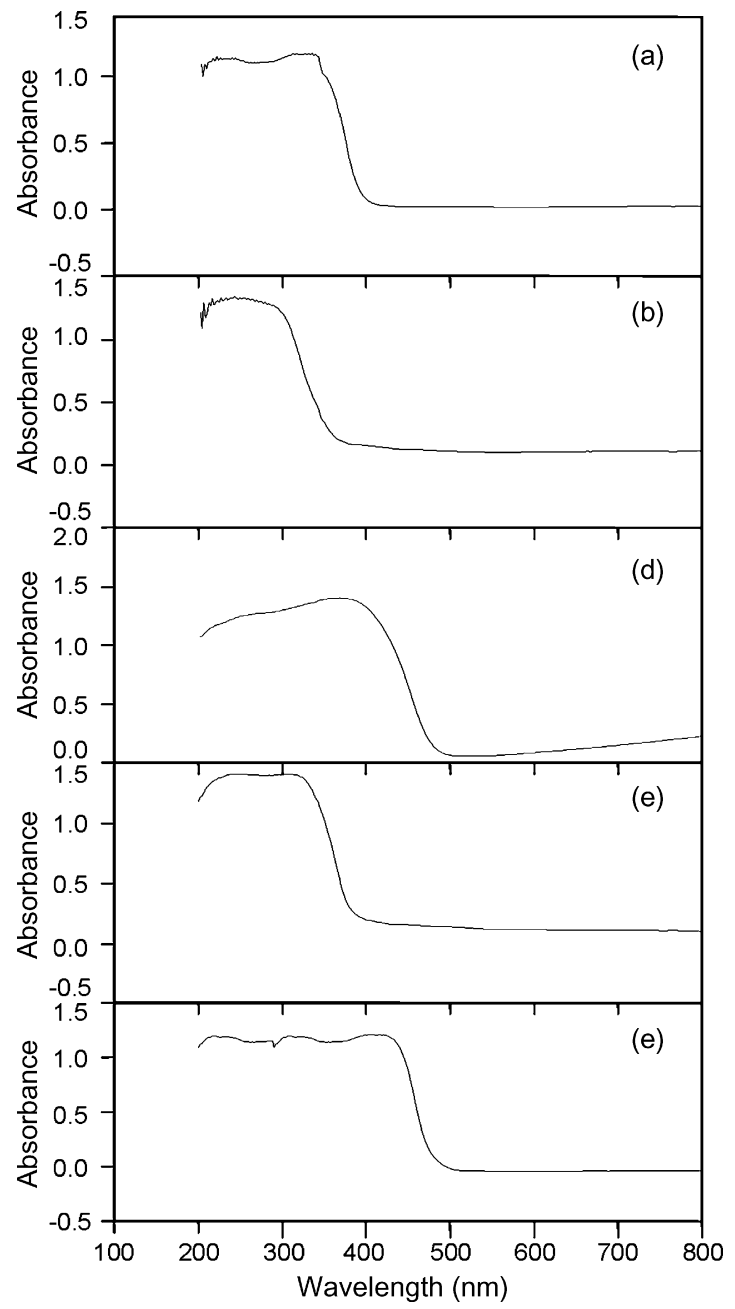

Fig. 1. The UV-vis spectrum of different catalyst (a) $\mathrm{TiO}_{2}$, (b) $\mathrm{SnO}_{2}$, (c) $\mathrm{WO}_{3}$, (d) $\mathrm{TiO}_{2} / \mathrm{SnO}_{2}$, and (e) $\mathrm{TiO}_{2} / \mathrm{WO}_{3}$.

over the single $\mathrm{TiO}_{2}(390 \mathrm{~nm})$. In general, the results of band gap energy for $\mathrm{WO}_{3}$ and $\mathrm{TiO}_{2}$ are similar to those reported by others [14,22,23]; however, $\mathrm{SnO}_{2}(3.7 \mathrm{eV})$ is higher than that (3.54 eV) of Sakthivel et al. [24].

Fig. 2 shows the SEM images of two coupled semiconductors. Both demonstrate almost uniform morphologies with the size $\mathrm{TiO}_{2} / \mathrm{SnO}_{2}$ about $150 \mathrm{~nm}$ and $\mathrm{TiO}_{2} / \mathrm{WO}_{3}$ about $300 \mathrm{~nm}$. XRD analysis reveals that $\mathrm{TiO}_{2}$ consists of mostly the anatase phase (Fig. 3a). The intensity of the coupled $\mathrm{TiO}_{2} / \mathrm{SnO}_{2}$ catalyst is almost the same as that of $\mathrm{TiO}_{2}$ (Fig. $3 \mathrm{a}$ and c). However, there appears a separate phase of $\mathrm{SnO}_{2}$ present in the coupled $\mathrm{TiO}_{2} / \mathrm{SnO}_{2}$ (Fig. 3b and c). This may be relevant to the subsequent performance since others have reported no $\mathrm{SnO}_{2}$ structure could be detected in an $\mathrm{TiO}_{2} / \mathrm{SnO}_{2}$ system [25]. On the other hand, $\mathrm{WO}_{3}$ may be incorporated into $\mathrm{TiO}_{2}$ in the $\mathrm{TiO}_{2} / \mathrm{WO}_{3}$ system, since the diagrams for $\mathrm{TiO}_{2}$ and $\mathrm{TiO}_{2} / \mathrm{WO}_{3}$ are exactly the same (Fig. 3a and e). The sharp peaks observed at $2 \theta=24.2^{\circ}$, $34.2^{\circ}, 49.8^{\circ}$ and $55.8^{\circ}$ (Fig. 3d) were indicative of the monoclinic $\mathrm{WO}_{3}$ [14]. It is noted that the initial molar ratio of $\mathrm{TiO}_{2}$ to $\mathrm{WO}_{3}$ was about $97: 3$, but the ESCA results (Table 1) indicate a much lower Ti:W ratio of 76:24.

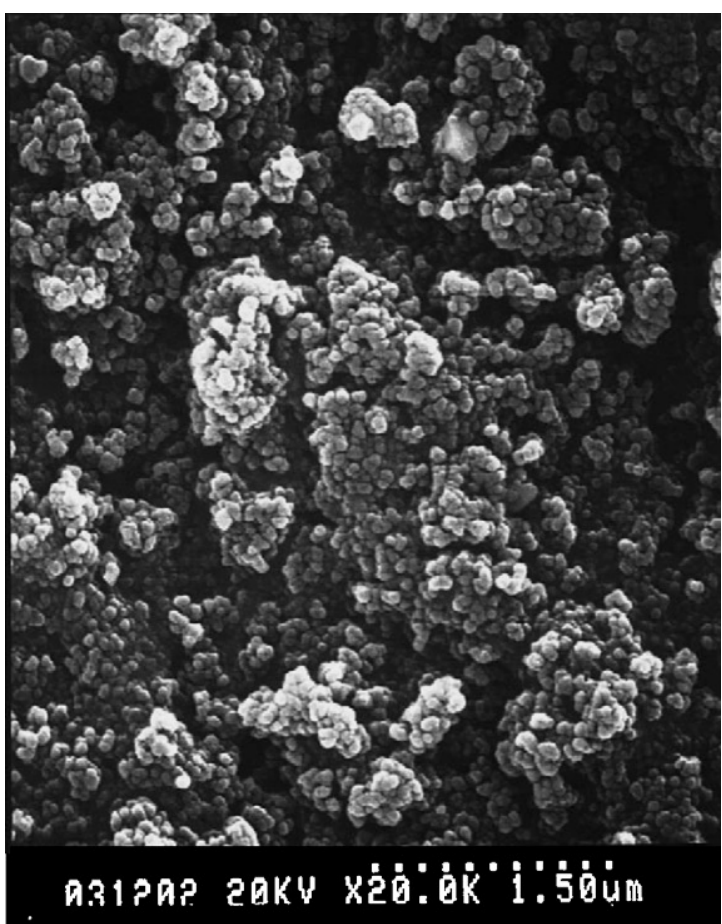

(a) $\mathrm{TiO}_{2} / \mathrm{SnO}_{2}$ (magnification: 20000)

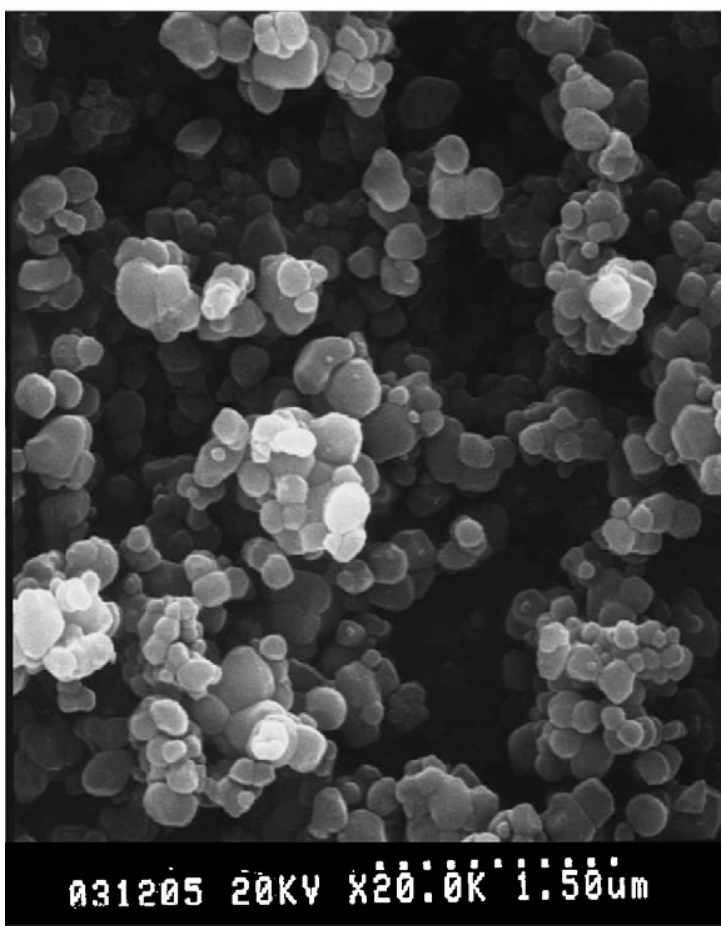

(b) $\mathrm{TiO}_{2} / \mathrm{WO}_{3}$ (magnification: 20000)

Fig. 2. SEM diagrams for coupled semiconductors (a) $\mathrm{TiO}_{2} / \mathrm{SnO}_{2}$ and (b) $\mathrm{TiO}_{2} / \mathrm{WO}_{3}$. 


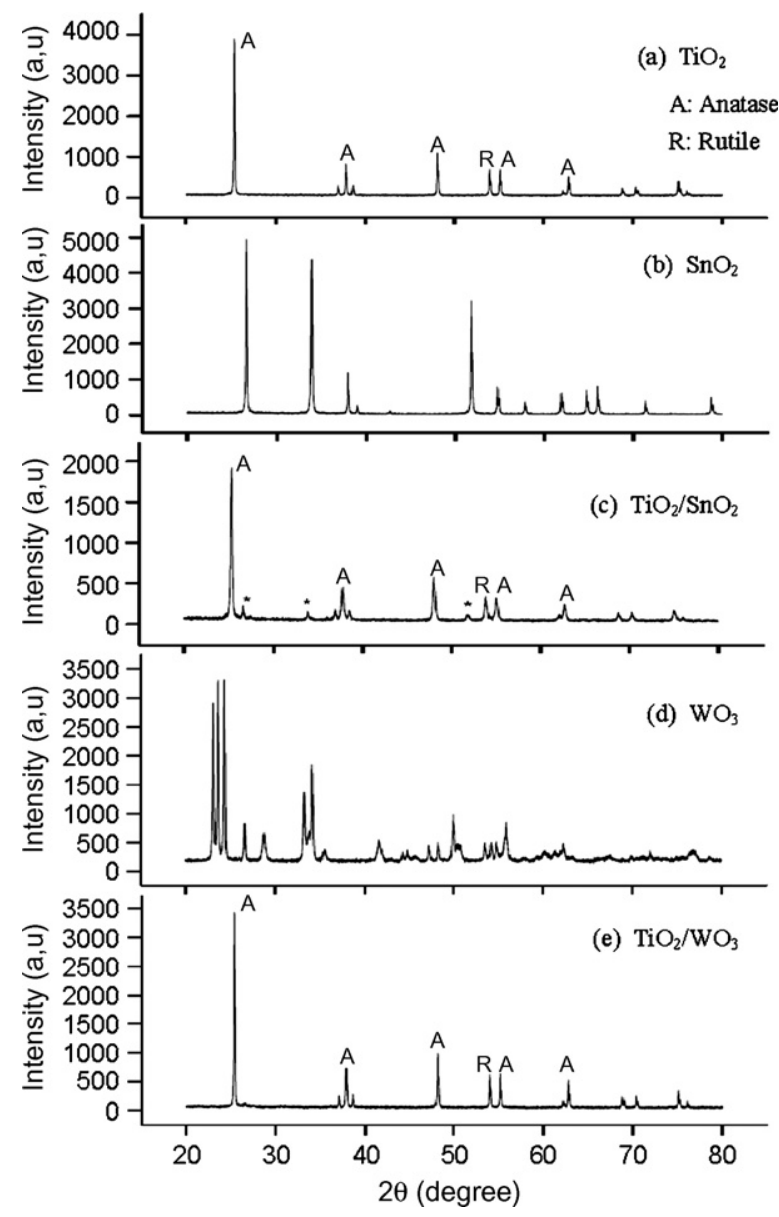

Fig. 3. XRD analysis of different semiconductors (a) $\mathrm{TiO}_{2}$, (b) $\mathrm{SnO}_{2}$, (c) $\mathrm{TiO}_{2} / \mathrm{SnO}_{2}$, (d) $\mathrm{WO}_{3}$, and (e) $\mathrm{TiO}_{2} / \mathrm{WO}_{3}$.

\section{2. $\mathrm{TiO}_{2} / \mathrm{WO}_{3}$ and single catalyst systems}

\subsubsection{4-CP degradation at $435 \mathrm{~nm}$}

The plots of 4-CP degradation at $\mathrm{pH} 7$ at wavelength $435 \mathrm{~nm}$ are shown in Fig. 4a, with the corresponding TOC and chloride released data shown in Fig. $4 \mathrm{~b}$ and c, respectively. The results clearly indicate that the removal of $4-\mathrm{CP}$ up to $65 \%$ could be attained at $180 \mathrm{~min}$ in the $\mathrm{TiO}_{2} / \mathrm{WO}_{3}$ system, whereas there was insignificantly reduction of 4-CP for either $\mathrm{TiO}_{2}$ or $\mathrm{WO}_{3}$ system. A much higher hydroxyl radical concentration is found for the $\mathrm{TiO}_{2} / \mathrm{WO}_{3}$ system (Fig. 5c). Fig. 4b data further indicate an accumulation of intermediates since TOC reduction was only $40 \%$ at $180 \mathrm{~min}$ with the corresponding theoretical chloride release of about $38 \%$.

In theory, the energy from the visible $435 \mathrm{~nm}$ light can only excite $\mathrm{WO}_{3}$ (band edge $450 \mathrm{~nm} ; 2.76 \mathrm{eV}$ ) and irradiated electrons are then transferring to the non-illuminated $\mathrm{TiO}_{2}$ (band edge $390 \mathrm{~nm} ; 3.18 \mathrm{eV}$ ), while the photoholes remained on $\mathrm{WO}_{3}$ [6] or transferred to $\mathrm{TiO}_{2}$ [22]. This electron transfer phenomenon resulting in a better charge separation may explain the observed higher efficiency of $\mathrm{TiO}_{2} / \mathrm{WO}_{3}$ system. On the other hand, the potential recombination of electrons and holes without interparticle electron transfer in the $\mathrm{WO}_{3}$ alone system results in its poor performance. Since energy

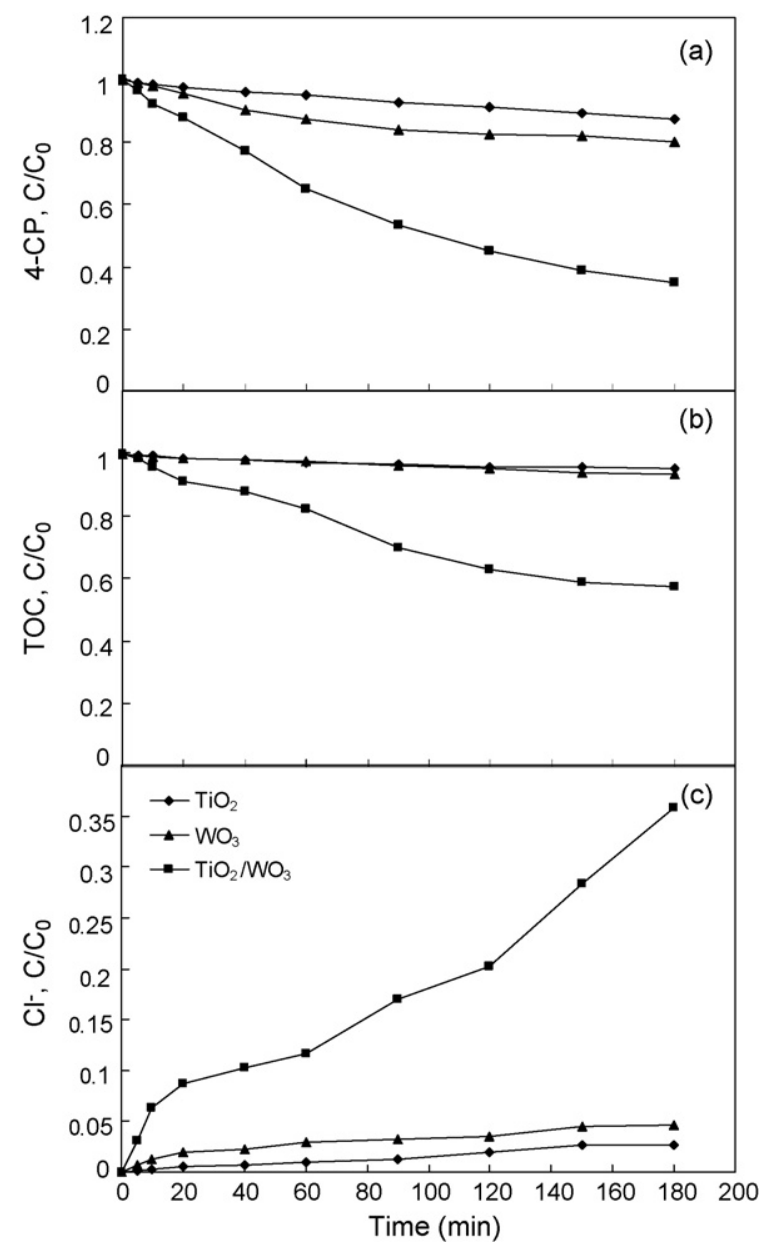

Fig. 4. Photodegradation of 4- $\mathrm{CP}$ at $\mathrm{pH} 7 \mathrm{in} \mathrm{TiO}_{2}, \mathrm{WO}_{3}$ and $\mathrm{TiO}_{2} / \mathrm{WO}_{3}$ systems at $435 \mathrm{~nm}, 4-\mathrm{CP} 2 \times 10^{-4} \mathrm{M}$, catalyst $1.2 \mathrm{~g} / \mathrm{L}, 50 \mathrm{~W}$ light, and $T=25^{\circ} \mathrm{C}$. (a) $4-\mathrm{CP}$, (b) TOC, and (c) chloride.

from $435 \mathrm{~nm}$ could hardly excite $\mathrm{TiO}_{2}$, its poor performance is expected. Literature is replete with a better photocatalytic performance in coupled systems, e.g., degradation of $\mathrm{CH}_{3} \mathrm{OH}$ in an $\mathrm{TiO}_{2} / \mathrm{WO}_{3}$ bilayer system with artificial sunrays [26], degradation of phenol and pentachlorophenol in an $\mathrm{CdS} / \mathrm{TiO}_{2}$ system at $406 \mathrm{~nm}$ [6].

\subsection{2. $p H$ effect}

The free hydroxyl radical concentration is highest for the $\mathrm{TiO}_{2} / \mathrm{WO}_{3}$ system at $\mathrm{pH} 4$ (Fig. 5b). 4-CP degradation as a function of $\mathrm{pH}$ is shown in Fig. 6. Lower $\mathrm{pH}$ favors the 4-CP degradation. The negatively changed of 4-CP (with a $\mathrm{p} K_{\mathrm{a}}$ of approximately 9.43) at $\mathrm{pH} 10$ may explain the poor performance at $\mathrm{pH}$ 10. The $\mathrm{pH}_{\mathrm{zpc}}$ (zero point charge) for $\mathrm{TiO}_{2}$ and $\mathrm{TiO}_{2} / \mathrm{WO}_{3}$ are 6.8 [24] and 6.4 [27], respectively. Thus, at $\mathrm{pH} \mathrm{4,} \mathrm{posi-}$ tively charged $\mathrm{TiO}_{2} / \mathrm{WO}_{3}$ surface exists. Also, the irradiation time plays a significant factor in the overall 4-CP degradation. Since the 1 st-order rate constants between data up to $180 \mathrm{~min}$ and those of $480 \mathrm{~min}$ do not vary too much, all subsequent experiments were terminated at $t=180 \mathrm{~min}$. Table 2 summarizes all the observed 1 st-order rate constants under various conditions. 


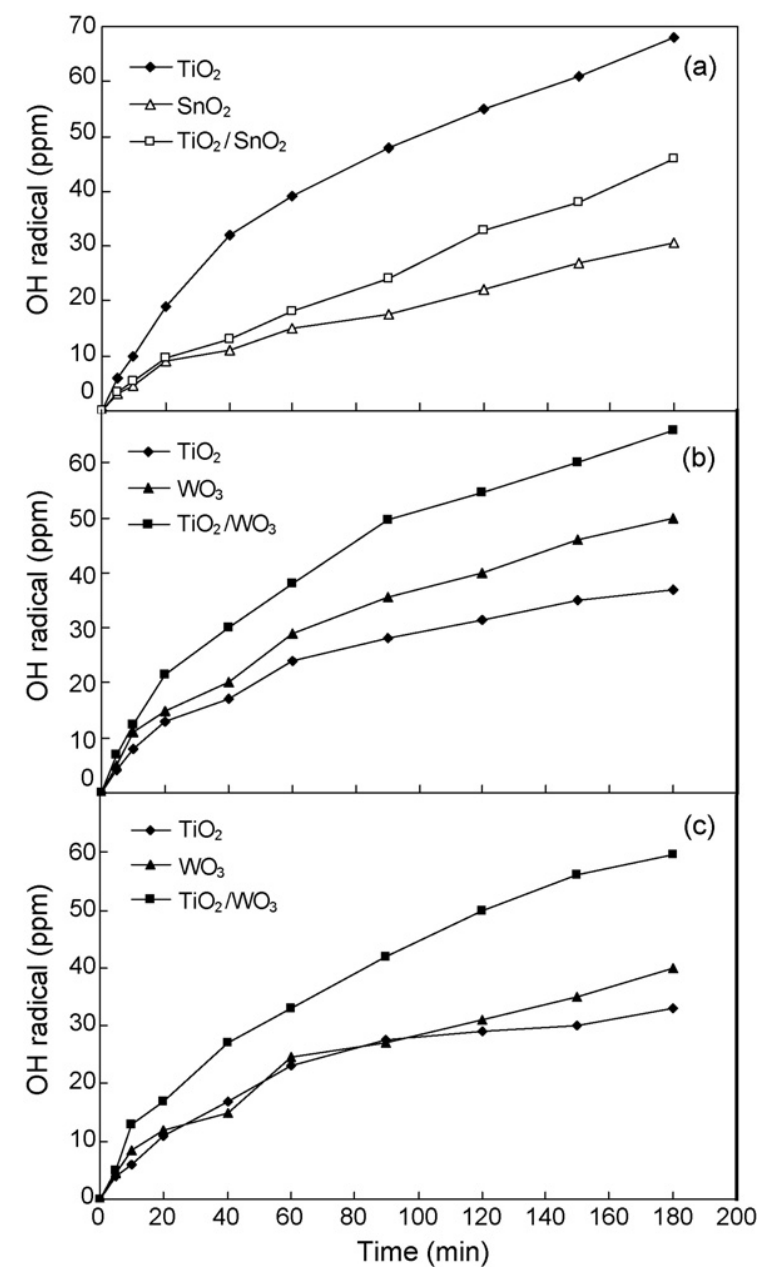

Fig. 5. Free hydroxyl radical concentrations (a) $\mathrm{pH} 4$ at $369 \mathrm{~nm}$, (b) $\mathrm{pH} 4$ at $435 \mathrm{~nm}$, and (c) $\mathrm{pH} 7$ at $435 \mathrm{~nm}$.

\subsubsection{4-CP degradation at $369 \mathrm{~nm}$}

The rationale for using $369 \mathrm{~nm}$ is that light energy could excite both $\mathrm{TiO}_{2}$ and $\mathrm{WO}_{3}$. In this way, it may lead to simultaneous electron transfer from $\mathrm{TiO}_{2}$ to $\mathrm{WO}_{3}$ and hole transfer from $\mathrm{WO}_{3}$ to $\mathrm{TiO}_{2}$ [6]. Thus, a better performance for the degradation of gaseous butyl acetate in the coupled $\mathrm{TiO}_{2} / \mathrm{WO}_{3}$ system at $350 \mathrm{~nm}$ [28], gaseous benzene and 2-propanol and liquid methyl blue [13], 1, 4-dichlorobenzene [16], gaseous 2-propanol [29] has been reported in the literature. Despite the enhanced performance with a better understanding of the increased surface

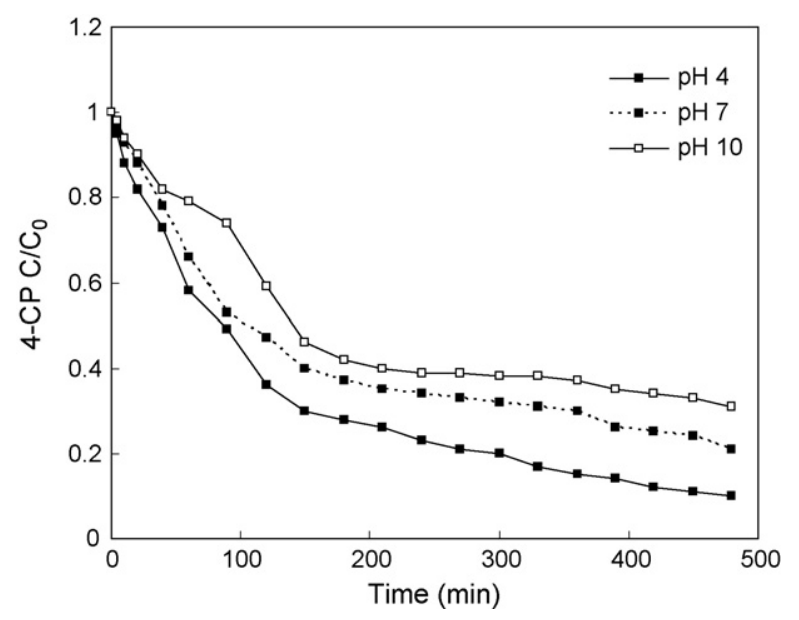

Fig. 6. Photodegradation of 4- $\mathrm{CP}$ as a function of $\mathrm{pH}$ in $\mathrm{TiO}_{2} / \mathrm{WO}_{3}$ system (light wavelength $=435 \mathrm{~nm}, 4-\mathrm{CP}=2 \times 10^{-4} \mathrm{M}$, catalyst $=1.2 \mathrm{~g} / \mathrm{L}$, light power $=50 \mathrm{~W}$ and $T=25^{\circ} \mathrm{C}$ ).

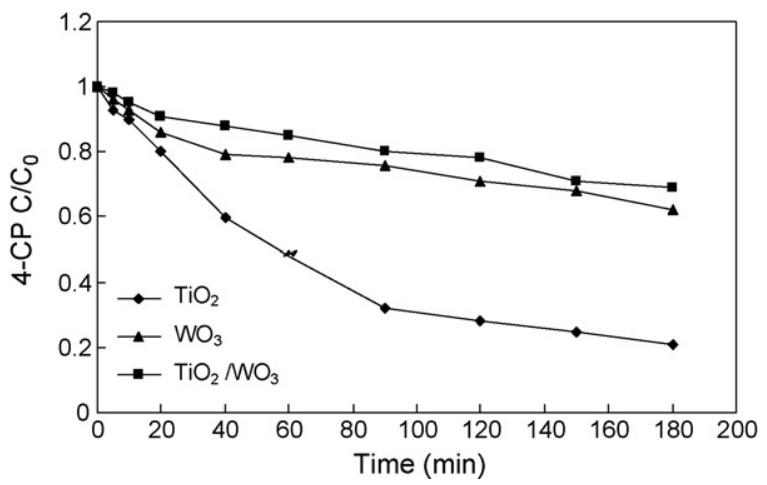

Fig. 7. Photodegradation of 4-CP at $\mathrm{pH} 7$ in $\mathrm{TiO}_{2}, \mathrm{WO}_{3}$ and $\mathrm{TiO}_{2} / \mathrm{WO}_{3}$ systems (light wavelength $=369 \mathrm{~nm}, 4-\mathrm{CP}=2 \times 10^{-4} \mathrm{M}$, catalyst $=1.2 \mathrm{~g} / \mathrm{L}$, light power $=50 \mathrm{~W}$, and $T=25^{\circ} \mathrm{C}$ ).

acidity [13,28], highly UV photoindcued hydrophilic character of the $\mathrm{TiO}_{2}$ surface in the presence of $\mathrm{WO}_{3}$ [22], and direct proof of electron transfer from $\mathrm{TiO}_{2}$ to $\mathrm{c}-\mathrm{WO}_{3}$ [14], the results of the present study are much different than those under $435 \mathrm{~nm}$ irradiation in that the coupled system performed poorly as compared to the single $\mathrm{TiO}_{2}$ or $\mathrm{WO}_{3}$ system (Fig. 7). In fact, the performance of $\mathrm{TiO}_{2}$ alone is the best; after $180 \mathrm{~min}$, only $20 \% 4$-CP remained in the single $\mathrm{TiO}_{2}$ system. For other $\mathrm{pH}$ results ( $\mathrm{pH} 4$ and 11), the trend is similar (data not shown). Others have also reported

Table 2

Photodegradation rate constant $\left(\mathrm{k}, \mathrm{h}^{-1}\right)$ in various systems

\begin{tabular}{|c|c|c|c|c|c|c|}
\hline \multirow[t]{3}{*}{ Semiconductor } & \multicolumn{6}{|c|}{ Wavelength (nm) } \\
\hline & \multicolumn{3}{|l|}{369} & \multicolumn{3}{|l|}{435} \\
\hline & $\mathrm{pH} 4$ & pH 7 & $\mathrm{pH} 10$ & $\mathrm{pH} 4$ & pH 7 & $\mathrm{pH} 10$ \\
\hline $\mathrm{TiO}_{2}$ & $1.068(0.944)$ & $0.708(0.977)$ & $0.504(0.951)$ & $0.078(0.954)$ & $0.003(0.958)$ & $0.042(0.707)$ \\
\hline $\mathrm{SnO}_{2}$ & $0.060(0.789)$ & $0.090(0.923)$ & $0.204(0.972)$ & $0.036(0.883)$ & $0.003(0.922)$ & $0.042(0.989)$ \\
\hline $\mathrm{TiO}_{2} / \mathrm{SnO}_{2}$ & $0.204(0.955)$ & $0.306(0.989)$ & $0.366(0.985)$ & $0.120(0.858)$ & $0.003(0.978)$ & $0.060(0.972)$ \\
\hline $\mathrm{WO}_{3}$ & $0.222(0.978)$ & $0.378(0.970)$ & $0.102(0.986)$ & $0.096(0.977)$ & $0.108(0.948)$ & $0.078(0.953)$ \\
\hline $\mathrm{TiO}_{2} / \mathrm{WO}_{3}$ & $0.180(0.983)$ & $0.132(0.950)$ & $0.108(0.963)$ & $0.504(0.997)$ & $0.378(0.989)$ & $0.288(0.981)$ \\
\hline
\end{tabular}

The values in parenthesis are $R^{2}$. 


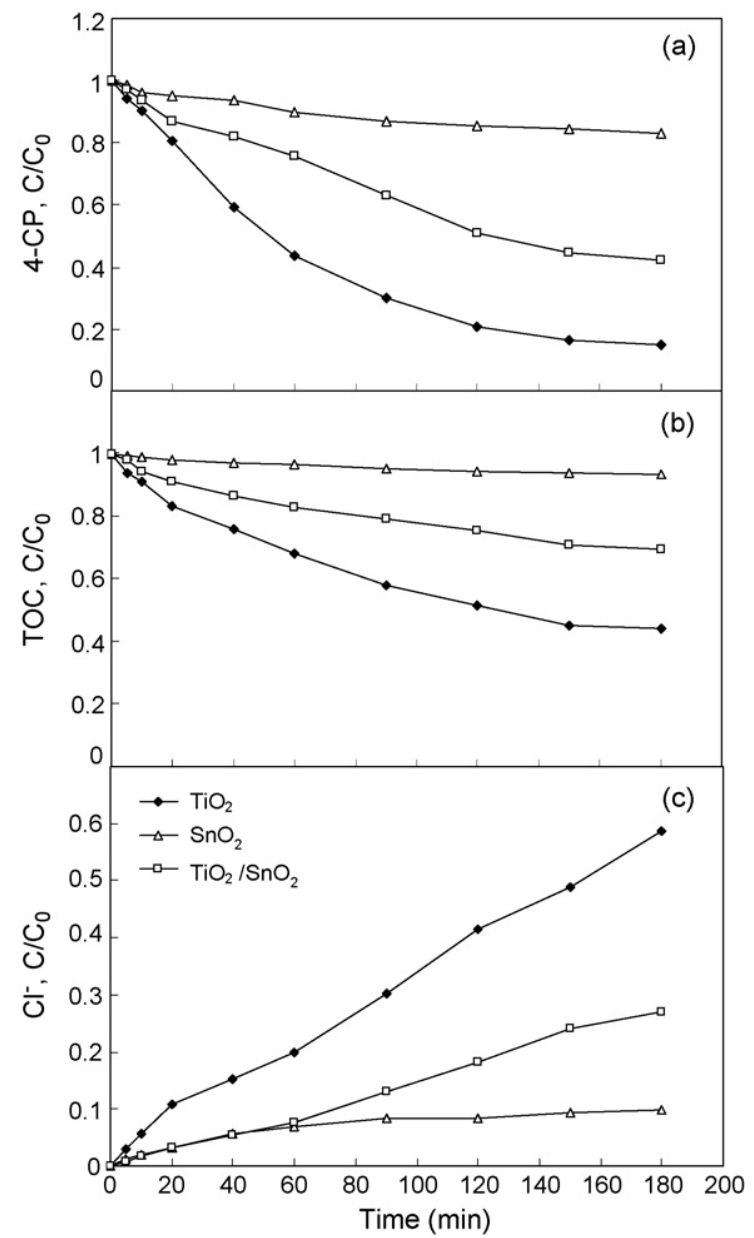

Fig. 8. Photodegradation of 4-CP at $\mathrm{pH} 7$ in $\mathrm{TiO}_{2}, \mathrm{SnO}_{2}$ and $\mathrm{TiO}_{2} / \mathrm{SnO}_{2}$ systems at $369 \mathrm{~nm}, 4-\mathrm{CP} 2 \times 10^{-4} \mathrm{M}$, catalyst $1.2 \mathrm{~g} / \mathrm{L}, 50 \mathrm{~W}$ light, and $T=25^{\circ} \mathrm{C}$. (a) $4-\mathrm{CP}$, (b) TOC, and (c) chloride.

a poor photoactivity of the coupled $\mathrm{TiO}_{2} / \mathrm{WO}_{3}$ system for phenol degradation at $\mathrm{pH} 3$ and $355 \mathrm{~nm}[6]$ and gaseous oxidation of $\mathrm{CH}_{3} \mathrm{CHO}$ and liquid-phase degradation of 2-naphthol [14]. Tada et al. [14] attributed the poor performance to the decrease in the rate of electron transfer from the semiconductors to $\mathrm{O}_{2}$. Keller et al. [28] further discussed the adverse effect of a high load of $\mathrm{TiO}_{2} / \mathrm{WO}_{3}$ in that it could act as recombination centers for electron-hole pairs resulting in the reduced efficiency. Unfortunately, the exact reason(s) for the observed poor performance of $\mathrm{TiO}_{2} / \mathrm{WO}_{3}$ is unclear.

\section{3. $\mathrm{TiO}_{2} / \mathrm{SnO}_{2}$ and single catalyst systems}

\subsubsection{4-CP degradation at $369 \mathrm{~nm}$}

Fig. 8 shows the 4-CP and TOC removal as well as the corresponding chloride release at $369 \mathrm{~nm}$. The addition of $\mathrm{SnO}_{2}$ onto $\mathrm{TiO}_{2}$ does not enhance the photooxidation of 4-CP; $\mathrm{TiO}_{2}$ alone is the best with $85 \%$ 4-CP removal and $\mathrm{SnO}_{2}$ alone only removes about $20 \% 4$-CP after $180 \mathrm{~min}$. The hydroxyl radical concentrations follow the same trend, i.e., $\mathrm{TiO}_{2}$ yields the highest concentration (Fig. 5a). Again, there is a significant accumulation of intermediates (Fig. 8b). In the presence of $\mathrm{SnO}_{2}$, the hydrophilicity of the coupled $\mathrm{TiO}_{2} / \mathrm{SnO}_{2}$ system increases

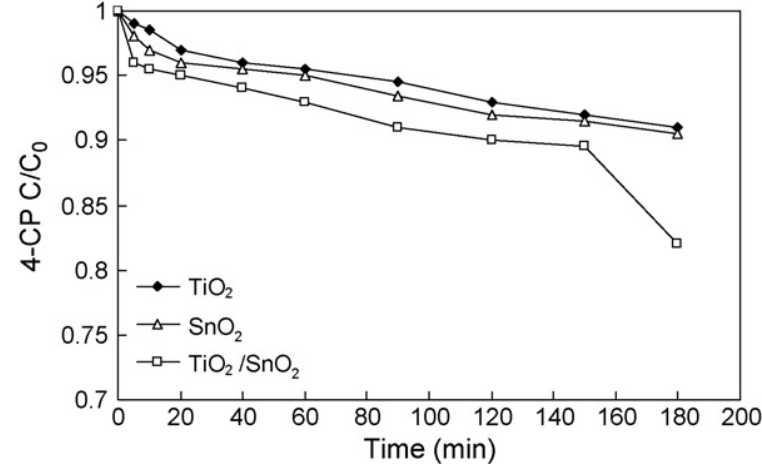

Fig. 9. Photodegradation of 4- $\mathrm{CP}$ at $\mathrm{pH} 7 \mathrm{in} \mathrm{TiO}_{2}, \mathrm{SnO}_{2}$ and $\mathrm{TiO}_{2} / \mathrm{SnO}_{2}$ systems (light wavelength $=435 \mathrm{~nm}, 4-\mathrm{CP}=2 \times 10^{-4} \mathrm{M}$, catalyst $=1.2 \mathrm{~g} / \mathrm{L}$, light power $=50 \mathrm{~W}$ and $T=25^{\circ} \mathrm{C}$ ).

[30]; this characteristic should not inhibit 4-CP degradation. Literature indicates, however, a better performance of the coupled $\mathrm{TiO}_{2} / \mathrm{SnO}_{2}$ systems, e.g., dehydrogenation of methanol at $320-400 \mathrm{~nm}$ [8]. Despite the electron transfer from $\mathrm{TiO}_{2}$ $(390 \mathrm{~nm} ; 3.18 \mathrm{eV})$ to $\mathrm{SnO}_{2}(335 \mathrm{~nm})$, Pilkenton and Raftery [23] reported that $\mathrm{SiO}_{2} / \mathrm{TiO}_{2}$ or $\mathrm{TiO}_{2} / \mathrm{SnO}_{2}$ film was less active in photodegradation of ethanol than a single $\mathrm{TiO}_{2}$ system. They attributed the buildup of intermediates on the catalysts surface. Serpone et al. [6] also reported no improved phenol degradation for $\mathrm{TiO}_{2} / \mathrm{SnO}_{2}$ as compared to $\mathrm{TiO}_{2}$ at $355 \mathrm{~nm}$. The lower efficiency observed in the preset study may be due to the amount of $\mathrm{SnO}_{2}$ incorporated into $\mathrm{TiO}_{2}$, since its quantity influences the photoactivity [9]. As for 4-CP degradation at $435 \mathrm{~nm}$, the poor performance (Fig. 9) is expected since the visible light cannot excite $\mathrm{TiO}_{2}$ nor $\mathrm{SnO}_{2}$. The $\mathrm{TiO}_{2} / \mathrm{SnO}_{2}$ system only slightly improved the 4-CP degradation, if any.

\section{Conclusion}

To enhance 4-CP degradation rate and using the visible light energy source, the present study used two coupled systems, $\mathrm{TiO}_{2} / \mathrm{WO}_{3}$ and $\mathrm{TiO}_{2} / \mathrm{SnO}_{2}$. The important findings of this study were presented below.

1. The band edge wavelength increased to $475 \mathrm{~nm}$, gap energy decreased to $2.61 \mathrm{eV}$ and the specific surfaces area reduced to $37 \mathrm{~m}^{2} / \mathrm{g}$ in the $\mathrm{TiO}_{2} / \mathrm{WO}_{3}$ system as compare to the single $\mathrm{TiO}_{2}$.

2. In the $\mathrm{TiO}_{2} / \mathrm{WO}_{3}$ system, the degradation efficiency significantly increased as compared to single $\mathrm{TiO}_{2}$ or $\mathrm{WO}_{3}$ system at $435 \mathrm{~nm}$ wavelength. However, the $\mathrm{TiO}_{2} / \mathrm{WO}_{3}$ degradation of 4-CP at $369 \mathrm{~nm}$ was in fact inhibited.

3. In $\mathrm{TiO}_{2} / \mathrm{SnO}_{2}$ system, the degradation efficiency also suffered at $369 \mathrm{~nm}$, and only slightly increased at $435 \mathrm{~nm}$ as compared to single $\mathrm{TiO}_{2}$ or $\mathrm{SnO}_{2}$ system.

\section{Acknowledgement}

The authors would like to thank the National Science Council of the Republic of China for financially supporting this research under Contract No. NSC 92-2211-E-002-007. 


\section{References}

[1] A. Ikeda, C. Abe, T. Torimoto, B. Ohtani, Photochemical hydrogen evolution from aqueous triethanolamine solutions sensitized by binaphtholmodified titanium(IV) oxide under visible-light irradiation, J. Photochem. Photobiol. A: Chem. 160 (2003) 61-67.

[2] V. Iliev, D. Tomova, L. Bilyarska, L. Prahov, L. Petrov, Phthalocyanine modified $\mathrm{TiO}_{2}$ or $\mathrm{WO}_{3}$-catalysts for photooxidation of sulfide and thiosulfate ions upon irradiation with visible light, J. Photochem. Photobiol. A: Chem. 159 (2003) 281-287.

[3] K. Gurunathan, Photocatalytic hydrogen production using transition metal ions-doped gamma- $\mathrm{Bi}_{2} \mathrm{O}_{3}$ semiconductor particles, Int. J. Hydrogen Energy 29 (2004) 933-940.

[4] T. Ohno, T. Mitsui, M. Matsumura, Photocatalytic activity of S-doped $\mathrm{TiO}_{2}$ photocatalyst under visible light, Chem. Lett. 32 (2003) 364-365.

[5] N. Serpone, E. Borgarello, M. Gratzel, Visible-light induced generation of hydrogen from $\mathrm{H}_{2} \mathrm{~S}$ in mixed semiconductor dispersions-improved efficiency through inter-particle electron-transfer, J. Chem. Soc. Chem. Commun. 6 (1984) 342-344.

[6] N. Serpone, P. Maruthamuthu, P. Pichat, E. Pelizzetti, H. Hidaka, Exploiting the interparticle electron-transfer process in the photocatalyzed oxidation of phenol, 2-chlorophenol and pentachlorophenol-chemical evidence for electron and hole transfer between coupled semiconductors, J. Photochem. Photobiol. A: Chem. 85 (1995) 247-255.

[7] R.A. Doong, C.H. Chen, R.A. Maithreepala, S.M. Chang, The influence of $\mathrm{pH}$ and cadmium sulfide on the photocatalytic degradation of 2-chlorophenol in titanium dioxide suspensions, Water Res. 35 (2001) 2873-2880.

[8] T. Kawahara, Y. Konishi, H. Tada, N. Tohge, S. Ito, Patterned $\mathrm{TiO}_{2} / \mathrm{SnO}_{2}$ bilayer type photocatalyst. 2. Efficient dehydrogenation of methanol, Langmuir 17 (2001) 7442-7445.

[9] Q.J. Liu, X.K. Yang, Q. Liu, B.L. Wang, X.H. Wu, Super-hydrophilicity of $\mathrm{TiO}_{2} / \mathrm{SnO}_{2}$ composite film, J. Inorg. Mater. 18 (2003) 1331-1336.

[10] J. Shang, W.Q. Yao, Y.F. Zhu, N.Z. Wu, Structure and photocatalytic performances of glass $/ \mathrm{SnO}_{2} / \mathrm{TiO}_{2}$ interface composite film, Appl. Catal. A: Gen. 257 (2004) 25-32.

[11] H. Tada, Y. Konishi, A. Kokubu, S. Ito, Patterned $\mathrm{TiO}_{2} / \mathrm{SnO}_{2}$ bilayer type photocatalyst. 3. Preferential deposition of Pt particles on the $\mathrm{SnO}_{2}$ underlayer and its effect on photocatalytic activity, Langmuir 20 (2004) 3816-3819.

[12] R. Suarez-Parra, I. Hernandez-Perez, M.E. Rincon, S. Lopez-Ayala, M.C. Roldan-Ahumada, Visible light-induced degradation of blue textile azo dye on $\mathrm{TiO}_{2} / \mathrm{CdO}-\mathrm{ZnO}$ coupled nanoporous films, Solar Energy Mater. Solar Cells 76 (2003) 189-199.

[13] Y.T. Kwon, K.Y. Song, W.I. Lee, G.J. Choi, Y.R. Do, Photocatalytic behavior of $\mathrm{WO}_{3}$-loaded $\mathrm{TiO}_{2}$ in an oxidation process, J. Catal. 191 (2000) 192-199.

[14] H. Tada, A. Kokrubu, M. Iwasaki, S. Ito, Deactivation of $\mathrm{TiO}_{2}$ photocatalyst by coupling with $\mathrm{WO}_{3}$ and the electrochemically assisted high photocatalytic activity of $\mathrm{WO}_{3}$, Langmuir 20 (2004) 4665-4670.
[15] H. Lin, H. Kozuka, T. Yoko, Low-temperature crystallization of TiO2 films on arranged mono-layers by sol-gel method, Mol. Cryst. Liq. Cryst. 337 (1999) 217-220.

[16] Y.R. Do, W. Lee, K. Dwight, A. Wold, The effect of $\mathrm{WO}_{3}$ on the photocatalytic activity of $\mathrm{TiO}_{2}$, J. Solid State Chem. 108 (1994) 198-201.

[17] J.F. Jen, M.F. Leu, T.C. Yang, Determination of hydroxyl radicals in an advanced oxidation process with salicylic acid trapping and liquid chromatograph, J. Chromatogr. A 796 (1998) 283-288.

[18] C.H. Wu, Comparison of azo dye decolorization efficiency using UV/single semiconductor and UV/coupled semiconductor systems, Chemosphere 57 (2004) 601-608.

[19] C.H. Wu, G.P. Chang-Chien, W.S. Lee, Photodegradation of polychlorinated dibenzo-p-dioxins: comparison of photocatalysts, J. Hazard. Mater. 114 (2004) 191-197.

[20] C. Malagu, M.C. Carotta, E. Comini, G. Faglia, A. Giberti, V. Guidi, T.G.G. Maffeis, G. Martinelli, G. Sberveglieri, S.P. Wilks, Photo-induced unpinning of Fermi level in $\mathrm{WO}_{3}$, Sensors 5 (2005) 594-603.

[21] F. Sanchez, T. Lopez, Effect of the preparation method on the band gap of titania and platinum-titania sol-gel materials, Mater. Lett. 25 (1995) 271-275.

[22] M. Miyauchi, A. Nakajima, T. Watanabe, K. Hashimoto, Photoinduced hydrophilic conversion of $\mathrm{TiO}_{2} / \mathrm{WO}_{3}$ layered thin films, Chem. Mater. 14 (2002) 4714-4720.

[23] S. Pilkenton, D. Raftery, Solid-state NMR studies of the adsorption and photooxidation of ethanol on mixed $\mathrm{TiO}_{2}-\mathrm{SnO}_{2}$ photocatalysts, Solid State Nucl. Magn. Reson. 24 (2003) 236-253.

[24] S. Sakthivel, B. Neppolian, M.V. Shankar, B. Arabindoo, M. Palanichamy, V. Murugesan, Solar photocatalytic degradation of azo dye: comparison of photocatalytic efficiency of $\mathrm{ZnO}$ and $\mathrm{TiO}_{2}$, Solar Energy Mater. Solar Cells 77 (2003) 65-82.

[25] P. Peng, Y.Q. Ren, Preparation of non- $\mathrm{TiO}_{2}-\mathrm{SnO}_{2}$ composite film and its photocatalytic activity for toluene degradation, Chin. J. Catal. 24 (2003) 243-247.

[26] T. Takahashi, H. Nakabayashi, N. Yamada, J. Tanabe, Photocatalytic properties of $\mathrm{TiO}_{2} / \mathrm{WO}_{3}$ bilayers deposited by reactive sputtering, J. Vacuum Sci. Technol. A 21 (2003) 1409-1413.

[27] X.Z. Li, F.B. Li, C.L. Yang, W.K. Ge, Photocatalytic activity of WOx$\mathrm{TiO}_{2}$ under visible light irradiation, J. Photochem. Photobiol. A: Chem. 141 (2001) 209-217.

[28] V. Keller, P. Bernhardt, F. Garin, Photocatalytic oxidation of butyl acetate in vapor phase on $\mathrm{TiO}_{2}, \mathrm{Pt} / \mathrm{TiO}_{2}$ and $\mathrm{WO}_{3} / \mathrm{TiO}_{2}$ catalysts, J. Catal. 215 (2003) 128-138.

[29] K.Y. Song, M.K. Park, Y.T. Kwon, H.W. Lee, W.J. Chung, W.I. Lee, Preparation of transparent particulate $\mathrm{MoO}_{3} / \mathrm{TiO}_{2}$ and $\mathrm{WO}_{3} / \mathrm{TiO}_{2}$ films and their photocatalytic properties, Chem. Mater. 13 (2001) 23492355.

[30] Q.J. Liu, X.H. Wu, B.L. Wang, Q.A. Liu, Preparation and super-hydrophilic properties of $\mathrm{TiO}_{2} / \mathrm{SnO}_{2}$ composite thin films, Mater. Res. Bull. 37 (2002) $2255-2262$ 